\title{
Digestion and fermentation of proteins in rats fed keratin, albumin, cooked casein and antibiotics
}

\author{
DE Corpet 1,2, R Bellier 3, S Petrowitsch 2, Y Vigouroux 2 \\ ${ }^{1}$ École Nationale Vétérinaire, 23 ch Capelles, 31076 Toulouse; \\ 2 INRA, Laboratoire des Xénobiotiques, BP 3, 31931 Toulouse; \\ 3 INRA, Station de Recherches Cunicoles, BP 27, 31326 Castanet-Tolosan, France
}

(Received 18 August 1993; accepted 17 November 1993)

\begin{abstract}
Summary - Dietary cooked casein promotes colon cancer in rats. We speculated and tested the hypothesis that cooking reduces the digestibility of casein, and increases the yield of bacterial metabolites, which are potential promoters of cancer. We investigated dietary means to manipulate nitrogen transfer and fermentation in the caecum. The caecal digestion of casein (cooked or not), keratin (hydrolysed or not) and bovine serum albumin (oxidized or not) was measured in rats. Protein fermentation was estimated by assaying caecal ammonia and branched-chain fatty acids. Keratin and cooked casein were digested to a very low extent, and were poorly fermented. Rats given cooked casein had 2-3 times more ammonia in their caecum than animals given the other proteins. Antibiotics (bacitracin, chlortetracycline, neomycin and spiramycin, at either 20 and $80 \mu \mathrm{g} / \mathrm{ml}$ water) decreased caecal ammonia in rats eating cooked casein, with spiramycin being most efficient. These data support the hypothesis given above, and provide ways to manipulate caecal ammonia.
\end{abstract}

protein / cooked casein / antibiotic / fermentation / digestion

Résumé - Digestion et fermentation des protéines chez des rats recevant de la kératine, de l'albumine, de la caséine cuite et des antibiotiques. La caséine cuite du régime est promotrice du cancer du côlon chez des rats initiés par l'azoxyméthane. Nous avons fait l'hypothèse que cet effet promoteur venait de la digestibilité réduite de la caséine cuite et de ses métabolites bactériens. Nous avons cherché une autre protéine qui soit peu digeste et bien fermentée. La digestibilité cæcale de l'azote a été mesurée chez des rats recevant un régime contenant de la caséine, cuite ou non, de la kératine, hydrolysée ou non, ou de l'albumine sérique bovine, oxydée ou non. L'ammoniaque et les acides gras volatils branchés ont été choisis comme marqueurs des fermentations cæcales. La caséine cuite et la kératine sont pratiquement indigestes et très peu fermentées. Les rats recevant la caséine cuite ont 2 à 3 fois plus d'ammoniaque dans le cæcum que les rats nourris des autres protéines. Les antibiotiques (bacitracine, chlortétracycline, néomycine ou spiramycine, à 20 ou $80 \mu \mathrm{g} / \mathrm{m} /$ d'eau de boisson) diminuent l'ammoniaque cæcal des rats mangeant de la caséine cuite, le plus efficace étant la spiramycine. Les résultats supportent l'hypothèse de départ et donnent des moyens de manipuler l'ammoniaque du cæcum. 


\section{INTRODUCTION}

International epidemiological studies show that risk of colon cancer is strongly correlated to protein intake (Doll and Peto, 1981). Analytical (case-cohort and casecontrol) studies show the association of risk with consumption of red and cooked meat (Willet et al, 1990; DeVerdier et al, 1991). Carcinogenesis studies in rats show that a diet containing a high level of protein promotes colon cancer (Topping and Visek, 1976). We showed that a diet containing cooked casein can also promote cancer in azoxymethane-initiated rats (Corpet et al, 1990; Zhang et al, 1992). The bacterial metabolites of protein entering the large bowel, namely ammonia, amines, phenols and indoles, might be responsible for cancer promotion (Cummings and Bingham, 1987; McBurney et al, 1987). Indeed, ammonium acetate promoted colon cancer in nitrosoguanidineinitiated rats (Clinton et al, 1988), but fecal ammonia did not differ between colon cancer cases and controls in a small (50 subjects) study (Clausen and Mortensen, 1992).

The nitrogen entering the large intestine comes from dietary proteins escaping small intestinal breakdown, endogenous proteins and mucins, and urea diffusing from blood (Demigné and Rémésy, 1979; Macfarlane and Cummings, 1991). Dietary carbohydrates escaping digestion are very efficient in depressing ammonia in the caecum (Levrat et al, 1993), and this might explain the protective effect of fiber against colon cancer (Cummings and Bingham, 1987; McBurney et al, 1987). The present study focused on dietary proteins. Most proteins are highly digestible in humans. Although collagen is insoluble in cold water, it is well digested in rats and in patients with ileostomies (Laser-Reutersward et al, 1985). Albumins (from milk, egg, or blood), keratin, and some cooked proteins, might escape small bowel digestion, and lead to high concentrations of fermentation products in the large bowel (Gibson et al, 1989). On the other hand, it might be possible to inhibit the colonic fermentation of proteins by the use of antibiotics (Michel, 1961).

Our aims were: (i) to measure the digestion and fermentation of the cancerpromoting cooked casein; (ii) to find a dietary protein that is poorly digested and highly fermented in the gut; and (iii) to find a way to decrease the fermentation of this protein in the gut. The main goal was to find ways of manipulating the release of bacterial metabolites of protein in the gut of rats during a carcinogenesis study, without changing the dietary fiber. We studied the digestibility and the fermentation products of cooked casein, bovine serum albumin and keratin in the rat caecum. Control groups of rats were given the same proteins in a more digestible form: raw casein, oxidized albumin, vapor-heated keratin. We also attempted to inhibit the cooked casein fermentation by giving antibiotics to the rats via drinking water.

\section{MATERIALS AND METHODS}

\section{Proteins}

Vitamin-free casein came from ICN (Buckinghamshire, UK) and cooked casein was obtained by cooking a thin layer of dry casein for $2 h$ at $180^{\circ} \mathrm{C}$ in an electric oven (Corpet et al, 1990).

Bovine serum albumin was purchased from Sigma (St Quentin, France), and half of it was oxidized by performic acid: $60 \mathrm{ml} 33 \%(\mathrm{w} / \mathrm{w})$ hydrogen peroxide (Sigma) and 1.1 । $99 \%$ formic acid (Sigma) were reacted at $25^{\circ} \mathrm{C}$ for $2 \mathrm{~h}$ ). The mixture was cooled in an ice-salt bath to $-5^{\circ} \mathrm{C}$ for $30 \mathrm{~min}$. A solution of $50 \mathrm{~g}$ serum albumin in $560 \mathrm{ml}$ formic acid and $125 \mathrm{ml}$ ethanol was also cooled. The 2 solutions were mixed and kept at $-5^{\circ} \mathrm{C}$ for $3 \mathrm{~h}$. Then $15 \mathrm{ml} 50 \%$ sodium sulfite 
was added to destroy excess performic acid The reaction mixture was dialyzed for $24 \mathrm{~h}$ against cold water, and then freeze-dried. This procedure specifically breaks disulfide bonds (Mahadevan et al, 1980).

Native keratin was obtained by grinding pigeon feathers $(90.7 \%$ protein). This substrate was hydrolyzed by vapor-heating the feathers twice for $50 \mathrm{~min}\left(120^{\circ} \mathrm{C}\right)$, followed by drying at $60^{\circ} \mathrm{C}$ (McCasland and Richardson, 1966).

\section{Diets}

Food components were purchased from ICN, except for tallow, starch, sucrose and corn oil, which were obtained from UAR (Villemoisson, France), and chromium oxide $\left(\mathrm{Cr}_{2} \mathrm{O}_{5}\right)$ from Prolabo (Strasbourg, France). The faecal digestibility of raw and cooked casein was determined in rats given the modified high-fat AIN76 diet used in previous carcinogenesis studies, in which $20 \%$ fat was added at the expense of sucrose on a caloric basis (Corpet et al, 1990). The diet contained $(\mathrm{g} / \mathrm{kg})$ : raw or cooked casein 200; sucrose 235; beef tallow 200; corn starch 177; cellulose 59; AIN76 mineral mix 41; corn oil 35; raw casein 35; AIN76 vitamin mix 12; DL-methionine 3.6; and choline bitartrate 2.4 (AIN, 1977). The caecal digestibility and fermentation of keratin, albumin and cooked casein was determined in rats given a modified AIN76 diet, low in fat to avoid possible inhibition of gut flora by fatty acids escaping small bowel digestion. This diet contained $(\mathrm{g} / \mathrm{kg})$ : protein under study 150 ; raw casein 100; sucrose 445; starch 150; cellulose 50; corn oil 50; mineral mix 35; vitamin mix 10; methionine 3; choline bitartrate 2; and chromium oxide 5 (AIN, 1977). The effect of antibiotics was studied by using the same diet, containing $150 \mathrm{~g} / \mathrm{kg}$ of cooked casein.

\section{Faecal digestibility of caseins}

Twenty-eight Fisher 344 6-week-old female rats (Iffa Credo, L'Abresles, France) were housed 4 per cage and given the high-fat modified AIN76 diet. All rats were provided with a diet containing $3.5 \%$ casein, to which was added either $20 \%$ cooked casein (8 experimental rats), or $20 \%$ raw casein (12 control rats), or $20 \%$ powdered glass
( 8 rats for estimation of endogenous nitrogen). After more than $30 \mathrm{~d}$ on the diets, each rat was housed alone in a stainless-steel metabolism cage for $7 \mathrm{~d}$. Food intake and faecal output were recorded for the last $3 \mathrm{~d}$ of the week. Total nitrogen was assayed in the $3 \mathrm{~d}$ pooled faecal samples, and in the diet, by the micro-Kjeldahl method of Dumas (automatic analyzer LECO-FP 428). The apparent faecal digestibility of the nitrogen $(\mathrm{N})$ from the $20 \%$ raw or cooked casein was calculated according to the formula:

$$
d=\frac{(\text { dietary } N-\text { faecal } N+\text { endogenous } N)}{\text { dietary } N}
$$

\section{Caecal digestibility of proteins}

Twenty-four OFA 6-week-old female rats (Iffa Credo) were randomized $7 \mathrm{~d}$ after their arrival into 6 groups, and each group of rats was given for $8 \mathrm{~d}$ a diet containing $10 \%$ of casein plus $15 \%$ of one of the following proteins: casein; cooked casein; albumin; oxidized albumin; keratin; or hydrolyzed keratin. The rats were sacrificed with chloroform between 8 and $9 \mathrm{am}$. The caecum was removed and weighed, the content was homogenized by hand, and then aspirated in $1-\mathrm{ml}$ plastic syringes. Aliquots $(0.5 \mathrm{~g})$ were deep frozen in plastic microtubes. Total nitrogen was determined on caecal contents by the method of Kjeldahl, with the Nessler reagent (Sigma) and measured at $500 \mathrm{~nm}$. Chromium was determined on the same Kjeldahl digest after action of perchloric acid and the bichromate ion was measured at $350 \mathrm{~nm}$ (Lied et al, 1982). The apparent caecal digestibility of nitrogen was calculated according to the formula:

$$
d=1-((\text { caecal N / caecal Cr }) /(\operatorname{diet} N / \operatorname{diet} \mathrm{Cr}))
$$

The apparent caecal digestibility of the proteins under study was estimated by including in the calculation the relative amounts of the protein and casein in the diet, and the digestibility of raw casein.

\section{Caecal fermentation of proteins}

Caecal contents from the 24 rats given 1 of the 6 proteins described above were analyzed fur- 
ther to determine the fermentation of the proteins reaching this part of the bowel. Since bacterial metabolites are absorbed by the caecal mucosa, the caecal content was incubated immediately after removal for $6 \mathrm{~h}$ at $37^{\circ} \mathrm{C}$, in a 1 -ml plastic syringe that maintained anaerobiosis. Ammonia was determined in the supernatant of centrifuged diluted samples, by a spectrophotometric method using phenol nitroprusside, the blue indophenol being red at 570 nm (Sigma kit \# 640). Volatile fatty acids were determined by gas chromatography, by the method of Jouany (1982) adapted to a semicapillary column. After centrifugation with orthophosphoric acid, the supernatant was injected into a Chrompack CP9000. 4-Methylvaleric acid was used as an internal standard, and 3 different mixtures of 6 volatile fatty acids (C2C5) were used as external calibration standards. The area of peaks were converted to molar quantities with an integrator (Chromjet, Spectraphysic). In this analytical system, methybutyrate and isovalerate were gathered in a single peak. Molar quantities of isobutyrate, isovalerate and methylbutyrate were summed, and the resulting amount of branched-chain fatty acids was taken as a marker of protein fermentation (Macfarlane and Cummings, 1991; Macfarlane et al, 1992).

\section{Antibiotic inhibition of caecal fermentation}

Thirty-three OFA 6-week-old female rats (Iffa Credo) were randomized $7 \mathrm{~d}$ after their arrival to 11 cages of 3 , and for $11 \mathrm{~d}$ each group of rats was given a powdered AIN76 diet containing $10 \%$ of casein plus $15 \%$ of cooked casein. After $4 \mathrm{~d}$ on the diet, antibiotics were added for $7 \mathrm{~d}$ to the drinking water which was kept at $\mathrm{pH} 4$ with $\mathrm{HCl}$, to avoid drug degradation and proliferation of bacteria in the bottles. Rats in 2 cages were given acidified water without antibiotic ( 6 control rats), 1 group was given $4 \mathrm{mg} / \mathrm{ml}$ of both bacitracin and neomycin (3 decontaminated rats) (VanDerWaajj and Sturm, 1968). The 8 other groups were given chlortetracycline- $\mathrm{HCl}$, neomycin-sulfate, bacitracin-zinc or spiramycin, at 20 and $80 \mu \mathrm{g} / \mathrm{ml}$ water, to find the most efficient drug at low doses. All antibiotics were obtained from Sigma. The rats were killed with chloroform between 8 and 9 am the 7th day. The cae- cum was removed and weighed, contents treated as before. One syringe from each rat was deep frozen immediately, another was incubated anaerobically just after sampling for $6 \mathrm{~h}$ at $37^{\circ} \mathrm{C}$, then deep frozen. Ammonia was determined as described above. A duplication of the effect of $80 \mu \mathrm{g} / \mathrm{ml}$ spiramycin was done in 8 rats, which were compared to 8 control rats given pure water, both groups eating a diet containing $15 \%$ cooked casein.

\section{Statistics}

The results of each experiment were analyzed by a one-way analysis of variance with the Fischer's test, and when this was significant $(p<$ 0.05 ), differences between groups taken by pair were evaluated by the Student's $t$-test. Data are given in the text as means \pm standard deviations, and 2 -sided values of $p$.

\section{RESULTS}

\section{Faecal digestibility of caseins}

The apparent faecal digestibility of nitrogen in rats given raw casein was almost complete $(89.3 \pm 2.7 \%)$. In contrast, faecal digestibility of nitrogen in rats given a casein that had been cooked for $2 \mathrm{~h}$ at $180^{\circ} \mathrm{C}$ was much reduced $(40.7 \pm 3.9 \%, p<0.001)$. Rats given cooked casein ate more food than controls $(9.3 \pm 1.3$ vs $8.4 \pm 1.1 \mathrm{~g} / \mathrm{d}$, $d f=78, p=0.001)$, but gained a little less weight $(0.77 \pm 0.07$ vs $0.83 \pm 0.08 \mathrm{~g} / \mathrm{d}, p=$ 0.12 , non-significant).

\section{Caecal digestibility of proteins}

Figure 1 shows that rats given either cooked casein or native keratin had much more nitrogenous matter in the caecum than rats given the other proteins. The corresponding caecal digestibilities, calcu- 

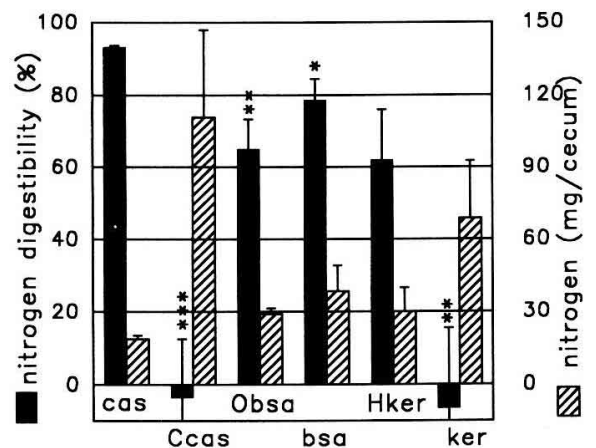

Fig 1. Digestibility of protein (black bars), and nitrogen content (hatched bars) in the caecum of rats given $15 \%$ of one of the following dietary proteins: casein cooked (Ccas) or not (cas); bovine serum albumin oxidized (Obsa) or not (bsa); or keratin hydrolyzed (Hker) or not (ker). Error bars are SEM. $p<0.05^{*}, 0.01^{* *}, 0.001$ *** compared with casein-fed rats.

lated from the ratio of caecal nitrogen vs chromium oxide, were $-3 \pm 32 \%$ and -6 $\pm 44 \%$ (both $p<0.01$ compared with $93 \pm$ $1 \%$ in controls given uncooked casein). One outlier rat given keratin was excluded from calculations (the caecum was full of keratin, digestibility of $-167 \%$ ). Oxidized albumin, native albumin and hydrolyzed keratin were less digestible than casein $(65 \pm$ $14,78 \pm 12,62 \pm 28$, respectively, $p=$ $0.01,0.04$ and 0.07 ), but much more digestible than keratin and cooked casein (see fig 1). The weight of rats fed for $8 d$ with cooked casein or native keratin was lighter than the weight of control rats (184 \pm 6 or $181 \pm 6$ vs $196 \pm 8 \mathrm{~g}$, both $p<0.05$ ). The other weight differences were not significant.

\section{Fermentation of proteins in the caecum}

Figure 2 shows the correlation between 2 markers of protein fermentation in incubated caecal samples: the ratios of ammonia

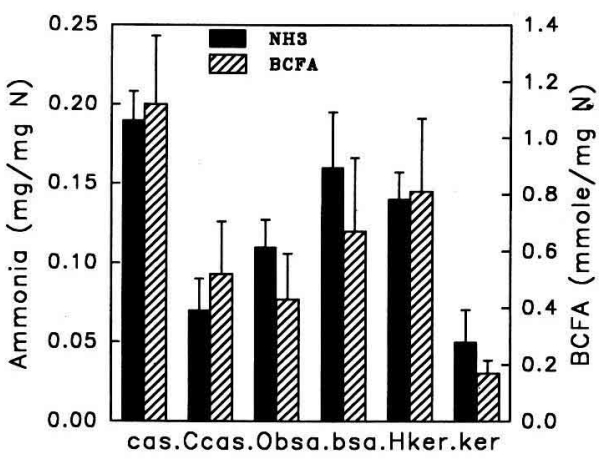

Fig 2. Markers of protein fermentation in the caecum of rats given various dietary proteins (see legend of fig 1). BFCA: branched-chain fatty acids.

and branched-chain fatty acids concentrations vs total nitrogen. The rat-by-rat correlation between both markers was $0.87(p<0.01)$. The fermentation of the various proteins was correlated to their digestibility shown in figure 1 (rat-by-rat correlation of $0.45, p<0.05$ ). The highly digestible raw casein yielded most ammonia and branched-chain fatty acids per $\mathrm{g}$ of caecal nitrogen, while the undigested keratin and cooked casein yielded the least fermentation products per $\mathrm{g}$ of nitrogen (both $p<0.01$ compared with uncooked casein).

\section{Caecal ammonia}

Figure 3 shows the caecal concentration of ammonia, measured before the in vitro incubation. This measurement integrates both the digestion and the fermentation of proteins, as well as the absorption by the mucosa. Rats fed cooked casein had considerably more ammonia in the caecum, and rats fed native albumin much less, than the other rats (both $p<0.01 \mathrm{com}$ pared with uncooked casein). The caecal ammonia in rats fed keratin, or processed 


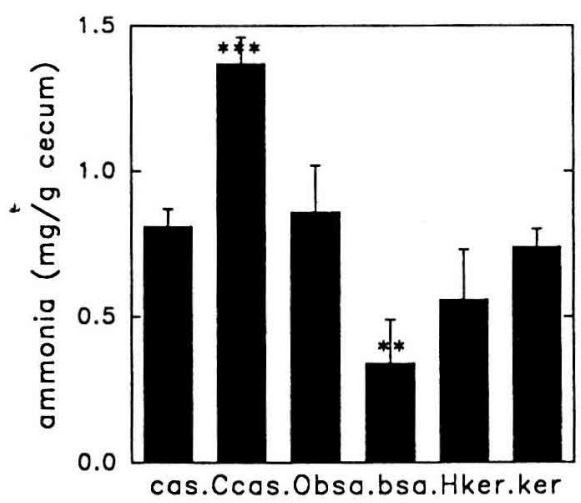

Fig 3. Caecal ammonia in rats given various proteins (see legend of figure 1).

keratin or albumin, was similar to the ammonia found in casein-fed rats.

\section{Antibiotic inhibition of caecal fermentations}

Figure 4 shows that in rats fed cooked casein, the administration of low doses of antibiotics via drinking water decreased

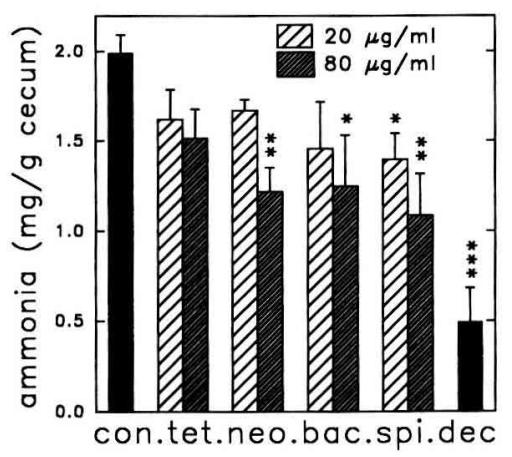

Fig 4. Inhibition of caecal fermentation by antibiotics given via drinking water to rats fed a diet with $15 \%$ of cooked casein: con: control rats given pure water; tet: chlortetracycline; neo: neomycin; bac: bacitracin; spi: spiramycin; dec: decontaminated rats, given both neomycin and bacitracin $4000 \mu \mathrm{g} / \mathrm{ml}$. the ammonia in incubated caeca. Spiramycin $(80 \mu \mathrm{g} / \mathrm{ml})$ was the most effective in decreasing the caecal ammonia (45\% decrease compared with control rats, $p=$ $0.004)$. It was, however, less active than high doses of antibiotics (75\% decrease, $p<0.001)$. Caecal weights were inversely correlated to the caecal ammonia concentrations $(r=-0.90, p<0.001)$. In the duplicate experiment involving 8 control rats and 8 rats given $80 \mu \mathrm{g} / \mathrm{ml}$ spiramycin, the antibiotic also decreased caecal ammonia, from $1.2 \pm 0.2$ to $0.8 \pm 0.1 \mathrm{mg} / \mathrm{g}(p=0.002)$.

\section{DISCUSSION}

The cooking of casein at $180^{\circ} \mathrm{C}$ for $2 \mathrm{~h}$ halved its faecal digestibility and reduced its caecal digestibility to zero. This marked loss of digestibility might explain its cancer-promoting properties. The discrepancy between faecal and caecal data must be due to the proteolysis by gut flora. Keratin was also not digested in the small bowel of rats, which is in contrast to vapor-heated keratin, as reported by McCasland and Richardson (1966). Thus, keratin seems a possible tool to increase the protein load in the colon of rats, and to mimic the cooked casein in carcinogenesis experiments. Moreover, if the cancer-promoting effect of cooked casein is due to its low digestion in the small bowel, we may speculate that humans eating proteins of low digestibility might be at risk for colon cancer. Testing this hypothesis would require the measurement of faecal nitrogen in a large human case-control study (Clausen and Mortensen, 1992). Bovine serum albumin was well digested in the small bowel of rat $(\approx 80 \%$, see fig 1 ), although pancreatic proteases from human ileal effluent do not hydrolyze this particular globular protein in vitro (Gibson et al, 1989). Oxidation of disulfide bonds did not improve the digestibility of serum albumin in rats (difference 
between albumin and oxidized albumin $p=$ 0.23 , see fig 1), while this treatment increases 10 -fold the hydrolysis by a microbial protease in vitro (Mahadevan et al, 1980). The reasons for these discrepancies between in vitro and in vivo results are not known.

There was a relationship between digestion and fermentation, and the least digested proteins were also the least fermented ones. This was previously shown for a range of proteins incubated in human ileal effluent and in human faeces (correlation $r=0.93, p=0.001$ calculated from Gibson et al, 1989). There was about twice as much ammonia and branched-chain fatty acids in the caecum of rats eating cooked casein than in rats eating the other proteins. Thus we may speculate that, as in human, this ammonia comes mainly from fermented proteins, and not from blood urea (Macfarlane and Cummings, 1991), since urea hydrolysis would not yield branched-chain fatty acids, and would be maximal in rats given highly digested proteins (Demigné and Rémésy, 1979). In another experiment, we found a 3 -fold difference in caecal ammonia between 9 rats given a diet containing 20\% raw casein, and 9 rats given 20\% cooked casein $(p<0.001$, data not shown). Since ammonia concentrations in rats are correlated with proliferation of colonic mucosa (Lin and Visek, 1991), and intrarectal instillations of ammonium acetate promote colon cancer in chemically induced rats (Clinton et al, 1988), it might be speculated that release of ammonia in the gut explains the cancer-promoting effect of cooked casein (Corpet et al, 1990; Zhang et al, 1992). This speculation should be confirmed by a specific trial, but it could not be done by using a diet containing keratin, since this protein was poorly fermented in rats (see figs 2 and 3).

The caecal fermentation of cooked casein was inhibited by the administration of antibiotics to the rats, and the most effi- cient molecule at these low concentrations was spiramycin. Similarly, spiramycin was found to be the most potent inhibitor of the arginine desamination by caecal flora from pigs, when compared with a range of 18 antibiotics in vitro (François and Michel, 1968). The decontamination by high doses of antibiotics led to a major decrease in caecal ammonia. However, this would not be a practical way of manipulating gut fermentation in a long-term carcinogenesis experiment, since the chances of contamination by resistant bacterial strains are high (VanDerWaajj and Sturm, 1968). The increase in the level of caecal ammonia due to the introduction of cooked casein instead of raw casein in the diet (from $1.5 \pm$ 0.3 to $2.1 \pm 0.6 \mathrm{mg} / \mathrm{g}$ ) could be counterbalanced by giving $80 \mu \mathrm{g} / \mathrm{ml}$ spiramycin in drinking water of rats given cooked casein (ammonia reduction from $2.0 \pm 0.3$ to $1.1 \pm$ $0.4 \mathrm{mg} / \mathrm{g}$ ). Hence spiramycin at low doses could be used to decrease protein fermentation in carcinogenesis experiments involving cooked casein.

Thus, cooked casein, like keratin, is not digested, and caecal ammonia is higher in rats eating cooked casein than any other protein, but can be decreased by the use of low doses of antibiotics.

\section{ACKNOWLEDGMENTS}

We thank R Gazel for the management of the animal care unit, J Bousset, WR Bruce, JP Laplace, C Rémésy, $Y$ Yin, $M$ Yvon and XM Zhang for discussions on undigested proteins, JP Cravedi for advice on chromium measurements, $B$ Lamboley and $V$ Pirot for the faecal $\mathrm{N}$ determinations, and JM Baradat for the loan of a Kjeldahl apparatus.

\section{REFERENCES}

AIN (1977) Report of the American Institute of Nutrition: Ad Hoc Committee on standards 
for nutritional studies. I Nutr 107, 13401348

Clausen MR, Mortensen PB (1992) Fecal ammonia in patients with adenomatous polyps and cancer of the colon. Nutr Cancer 18, 175-180

¿Clinton SK, Bostwick DG, Olson LM, Mangian HJ, Visek WJ (1988) Effect of ammonium acetate and sodium cholate on $\mathrm{N}$-methyl- $\mathrm{N}^{\prime}$ nitro- $N$-nitrosoguanidine-induced colon carcinogenesis of rats. Cancer Res 48, 30353039

Corpet DE, Stamp D, Medline A, Minkin S, Archer MC, Bruce WR (1990) Promotion of colonic microadenoma growth in mice and rats fed cooked sugar or cooked casein and fat. Cancer Res 50, 6955-6958

Cummings JH, Bingham SA (1987) Dietary fibre fermentation and large bowel cancer. Cancer Sun 6, 601-621

Demigné C, Rémésy C (1979) Urea cycling and ammonia absorption in vivo in the digestive tract of the rat. Ann Biol Anim Bioch Biophys 19, 929-935

DeVerdier MG, Hagman U, Peters RK, Steinek G, Overvik E (1991) Meat cooking methods and colorectal cancer - a case-referent study in Stockolm. Int J Cancer 49, 520-525

Doll R, Peto R (1981) The causes of cancer. $J$ Nat Cancer Inst 66, 1191-1308

François AC, Michel MC (1968) Mode d'action des antibiotiques sur la croissance. Nutr Dieta $10,35-59$

Gibson SAW, McFarlan C, Hay S, Macfarlane GT (1989) Significance of microflora in proteolysis in the colon. Appl Environ Microbiol $55,679-683$

Jouany JP (1982) Dosage des acides gras volatils et des alcools dans les contenus digestifs, les jus d'ensilage, les cultures bactériennes et les contenus de fermenteurs anaérobies. Sci Aliments 2, 131-144

Laser-Reutersward A, Asp NG, Bjorck I (1985) Protein digestibility of pigskin and bovine tendon in rats. J Food Technol 20, 745-752

Levrat MA, Rémésy C, Demigné C (1993) Influence of inulin on urea and ammonia nitrogen fluxes in the rat caecum: consequences on nitrogen excretion. J Nutr Biochem 4, 1-6
Lied E, Julshamn K, Braekkan OR (1982) Determination of protein digestibility in Atlantic cod with internal and external indicators. Can J Fish Aquat Sci 39, 854-861

Lin HC, Visek WJ (1991) Large intestinal $\mathrm{pH}$ and ammonia in rats: dietary fat and protein interactions. J Nutr 121, 832-843

Maciarlane GT, Cummings JH (1991) The colonic flora fermentation and large bowel digestive function. In: The Large Intestine, Physiology Pathophysiology and Disease (SF Phillips et al, eds) Raven Press, NY, 51-92

Macfarlane GT, Gibson GR, Beatty E, Cummings JH (1992) Estimation of short-chain fatty acid production from protein by human intestinal bacteria based on branched-chain fatty acid measurements. FEMS Microbiol Ecol 101, 81-88

Mahadevan S, Erfle JD, Sauer FD (1980) Degradation of soluble and insoluble proteins by Bacteroides amylophilus protease and by rumen microorganisms. J Anim Sci 50, 723728

McBurney Ml, VanSoest PJ, Jeraci JL (1987) Colonic carcinogenesis, the microbial feast or famine mechanism. Nutr Cancer 10, 23-28

McCasland WE, Richardson LR (1966) Methods for determining the nutritive value of feather meals. Poultry Sci 45, 1231-1236

Michel MC (1961) Activité métabolique de la flore totale isolée de lintestin de porc. Ann Biol Aniom Bioch Biophys 1, 16-28

Topping DC, Visek WJ (1976) Nitrogen intake and tumorigenesis in rats injected with 1,2dimethylhydrazine. J Nutr 106, 1583-1590

VanDerWaaij D, Sturm CA (1968) Antibiotic decontamination of the digestive tract of mice technical procedures. Lab Anim Care 18, 1-10

Willett WC, Stampfer MJ, Colditz GA, Rosner BA, Speizer FE (1990) Relation of meat fat and fiber intake to the risk of colon cancer in a prospective study among women. New Engl J Med 323, 1664-1672

Zhang XM, Stamp D, Minkin S, Medline A, Corpet DE, Bruce WR, Archer MC (1992) Promotion of aberrant crypt foci and cancer in rat colon by thermolyzed protein. $J$ Nat Cancer Inst 84, 1026-1030 